\title{
Enantioselective Antifungal Activity of Pefurazoate against Pathogens of Rice Seed Diseases
}

\author{
Mitsuaki TAKenAKa, ${ }^{*}$ Takashi Nishimura and Keisuke HAYASHI \\ Ube Research Laboratory, Ube Industries, Ltd., \\ Kogushi, Ube, Yamaguchi 755-8633, Japan
}

(Received May 1, 2000 ; Accepted June 27, 2001)

\begin{abstract}
Pefurazoate is a $14 \alpha$-demethylation inhibitor of 24-methylenedihydrolanosterol (24-MDL) and has an asymmetric carbon atom in its structure. We previously reported that the antifungal activity of the $(S)-(-)$-isomer of pefurazoate against Gibberella fujikuroi was about thirty times that of the $(R)-(+)-$ isomer. This enantioselective antifungal activity was presumed to be due to an asymmetric molecular shape caused by the binding of a bulky 2-furanylmethyl group to a nitrogen atom adjacent to the asymmetric carbon atom. Therefore, to further elucidate the difference in antifungal activity between the two enantiomers of pefurazoate, we synthesized optically active $N$-methyl analogues of pefurazoate, and evaluated their antifungal activity. Optical $(R)-(+)$ - and $(S)-(-)$-isomers of pefurazoate exhibited different activities against Cochliobolus miyabeanus and Pyricularia oryzae as well as Gibberella fujikuroi, but the $N$-methyl $(R)-(+)$ - and $(S)-(-)$-isomers of the pefurazoate analogues had almost the same degree of activity against these three fungi and of inhibition of ergosterol biosynthesis in G. fujikuroi. These findings strongly suggest that the enantioselective antifungal activity of pefurazoate is due to its asymmetric molecular shape caused by substitution of the furan ring.
\end{abstract}

Key words: pefurazoate, enantioselective antifungal activity, $14 \alpha$-demethylation inhibitor, Gibberella fujikuroi, Cochliobolus miyabeanus, Pyricularia oryzae.

\section{INTRODUCTION}

Pefurazoate $\{$ IUPAC name: pent-4-enyl $N$-furfuryl- $N$ imidazol-1-ylcarbonyl-DL-homoalaninate, CA name: 4pentenyl 2-[(2-furanylmethyl)( $1 H$-imidazol-1ylcarbonyl)amino] butanoate $\}$ is a novel imidazole compound registered as a rice seed disinfectant in Japan in 1989. ${ }^{1,2)}$ In our previous study, ${ }^{3)}$ pefurazoate was found to be a $14 \alpha$-demethylation inhibitor (DMI) of 24methylenedihydrolanosterol (24-MDL), in common with other azole fungicides.

A large number of azole fungicides have been launched in the agrochemical market. Stereochemically, many azole fungicides have more than one asymmetric carbon atom in their structures. The relationship between the stereoisomerism of these compounds and their biological activity is of particular interest. It has been reported that stereoisomers of azole compounds had different biological activities. ${ }^{4}$ As shown in Fig. 1, pefurazoate has an asymmetric carbon atom in its structure. Our previous study showed that the antifungal activity of the

\footnotetext{
${ }^{*}$ To whom correspondence should be addressed.
}

$(S)-(-)$-isomer $\mathbf{I b}$ of pefurazoate against Gibberella fujikuroi was about thirty times that of the $(R)-(+)$ isomer $\mathbf{I a} .{ }^{3)}$ This enantioselectivity in antifungal activity might be due to the conformational asymmetry due to the 2-furanylmethyl group at the nitrogen atom adjacent to the asymmetric carbon atom. Considering the site of interaction of pefurazoate as a $14 \alpha$-demethylation inhibitor, the presence of the bulky 2-furanylmethyl group might contribute to enantioselective antifungal activity. In the present study, we synthesized racemate (II) and optical isomers (IIa, IIb) of $N$-methyl analogues of pefurazoate, and compared their activities against Cochliobolus miyabeanus, Pyricularia oryzae and Gibberella fujikuroi with those of optical isomers of pefurazoate. We also studied their molecular shapes and enantioselective activity in the inhibition of ergosterol biosynthesis in $G$. fujikuroi.

\section{MATERIALS AND METHODS}

\section{Chemicals}

The chemicals used in this experiment are listed in Fig. 1. Pefurazoate racemate I (chemical purity: 99.16\%), $(R)-(+)$-isomer Ia (chemical purity: 98.19\%, optical 


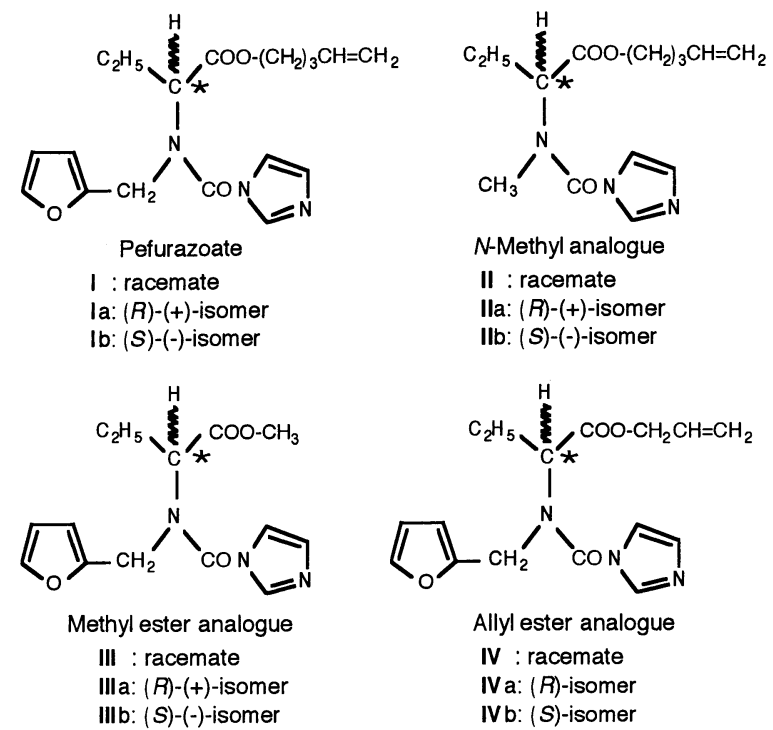

Fig. 1 Chemical structures of pefurazoate and its analogues. * Asymmetric carbon atom.

purity: $99.2 \%$ ee), $(S)-(-)$-isomer Ib (chemical purity: 96.26\%, optical purity: $99.3 \% e e$ ), methyl ester racemate III and allyl ester racemate IV were the same samples as used in our previous studies. ${ }^{3,5)} \mathrm{N}$-Methyl racemate (II), optical isomers (IIa, IIb) and the methyl ester isomers (IIIa, IIIb) shown in Fig. 1 were newly synthesized using a method similar to that reported previously. ${ }^{3)}$ Structures of the final compounds were confirmed by chemical ionization mass (CI-MS) spectra (Hitachi $\mathrm{M}-80 \mathrm{~A})$ and proton nuclear magnetic resonance $\left({ }^{1} \mathrm{H}\right.$ NMR) spectra (JEOL GSX-400, $400 \mathrm{MHz}$ ) using tetramethylsilane (TMS) as an internal standard. Optical rotations were measured with a digital polarimeter (JASCO DIP-140). Refractive indices were measured with an Abbe-refractometer (Atago 3T). Melting points were measured with a melting point apparatus (Yamato MP-21).

\section{Synthesis of Compounds}

Starting from 4-pentenyl ( $R S)$-2-bromobutanoate, pefurazoate $N$-methyl racemate II was synthesized by a method similar to that for the optical isomers IIa and IIb. Compound II was a yellowish oil $\left(n_{\mathrm{D}}^{24.8} 1.4954\right)$ and its total yield was $38 \%$. The preparations of optically active compounds IIa, IIb, IIIa and IIIb are outlined as follows.

\subsection{4-Pentenyl (R)-( + )-2-[N-(1 H-imidazol-1-ylcar- bonyl)methylamino] butanoate (IIa)}

Compound IIa was prepared by $N$-methylation of methyl $(R)$-( -$)$-2-aminobutanoate hydrochloride with methyl iodide and transesterification with 4-penten-1-ol, followed by the formation of carbamoyl chloride with trichloromethyl chloroformate (TCF) and reaction with imidazole. $^{3)}$ The crude oily product thus obtained was subjected to silica gel column chromatography (toluene/ ethyl acetate $=7 / 3, \mathrm{v} / \mathrm{v}$ ) to obtain IIa (total yield $1.0 \%$ ) as a pale yellowish oil. $n_{\mathrm{D}}^{20.0} 1.4533,[\alpha]_{\mathrm{D}}^{20}+47.4^{\circ}(c=$ 0.358, methanol), CI-MS $m / z: 280\left(\mathrm{MH}^{+}\right), 212,144,116$, 69. ${ }^{1} \mathrm{H}$ NMR $\delta_{\mathrm{TMS}}^{\mathrm{CDCl}_{3}} \mathrm{ppm}: 1.01(3 \mathrm{H}, \mathrm{t}, J=7.3 \mathrm{~Hz}$, $\mathrm{CHCH}_{2} \mathrm{CH}_{3}$ ), 1.73-1.92 (3H, m, $\mathrm{CHCH}_{2} \mathrm{CH}_{3}, \mathrm{OCH}_{2} \mathrm{CH}_{2}$ $\left.\mathrm{CH}_{2} \mathrm{CH}=\overline{\mathrm{CH}}_{2}\right), 2.05-2.18\left(3 \mathrm{H}, \mathrm{m}, \overline{\mathrm{CH}}_{2} \mathrm{H}_{2} \mathrm{CH}_{3}, \mathrm{OC}_{2}\right.$ $\left.\mathrm{CH}_{2} \mathrm{CH}_{2} \mathrm{CH}=\mathrm{CH}_{2}\right), 3.05\left(3 \mathrm{H}, \mathrm{s}, \mathrm{NCH}_{3}\right), 4.20(2 \mathrm{H}, \mathrm{t}, J=$ $\left.6.6 \mathrm{~Hz}, \mathrm{OCH}_{2} \mathrm{CH}_{2} \mathrm{CH}_{2} \mathrm{CH}=\mathrm{CH}_{2}\right), 4.48-4.65(1 \mathrm{H}, \mathrm{br}$, methine), $4.98-5.09\left(2 \mathrm{H}, \mathrm{m}, \mathrm{OCH}_{2} \mathrm{CH}_{2} \mathrm{CH}_{2} \mathrm{CH}=\mathrm{CH}_{2}\right)$, 5.73-5.86 (1H, m, OCH $\left.\mathrm{CH}_{2} \mathrm{CH}_{2} \mathrm{CH}=\mathrm{CH}_{2}\right), 7.11(\overline{1} \mathrm{H}$, bs, imidazole), 7.25-7.28 (1H, m, imidazole $), 7.93(1 \mathrm{H}$, bs, imidazole).

2.2 4-Pentenyl (S)-(-)-2-[N-(1H-imidazol-1-ylcarbonyl)methylamino] butanoate (IIb)

Starting from methyl $(S)-(+)$-2-aminobutanoate hydrochloride, compound IIb was prepared by the same method as for compound IIa.

Compound IIb was confirmed by CI-MS and ${ }^{1} \mathrm{H}$ NMR spectra. $n_{\mathrm{D}}^{20.0} 1.4512,[\alpha]_{\mathrm{D}}^{20}-39.8^{\circ}(c=0.713$, methanol $)$. 2.3 Methyl (R)-( + )-2-[(2-furanylmethyl) (1 Himidazol-1-ylcarbonyl)amino] butanoate (IIIa)

Compound IIIa was prepared using a procedure similar to that for compound IIa, starting from methyl $(R)$ $(-)$-2-aminobutanoate hydrochloride. The synthesis was performed by $N$-furfurylation of methyl $(R)-(-)-2-$ aminobutanoate hydrochloride with furfuryl chloride, followed by formation of carbamoyl chloride with TCF and reaction with imidazole. ${ }^{3)}$ The crude product thus obtained was subjected to silica gel column chromatography $(n$-hexane/ethyl acetate $=1 / 1, \mathrm{v} / \mathrm{v})$ to obtain IIIa as a pale yellowish oil (total yield $27 \%$ ), which crystallized later. $\mathrm{mp} 42-43^{\circ} \mathrm{C}$ (recrystallized from $n$-hexane).

$[\alpha]_{\mathrm{D}}^{20}+4.1^{\circ}(c=10.0$, methanol $)$, CI-MS $\mathrm{m} / z: 292$ $\left(\mathrm{MH}^{+}\right), 224,149,81,69 .{ }^{1} \mathrm{H}$ NMR $\delta_{\mathrm{TMS}}^{\mathrm{CDCl}_{3}} \mathrm{ppm}: 0.76(3 \mathrm{H}$, $\left.\mathrm{t}, J=7.3 \mathrm{~Hz}, \mathrm{CHCH}_{2} \mathrm{CH}_{3}\right), 1.94-2.14\left(2 \mathrm{H}, \mathrm{m}, \mathrm{CHC}_{2}\right.$ $\left.\mathrm{CH}_{3}\right), 3.75\left(3 \mathrm{H}, \mathrm{s}, \mathrm{OCH}_{3}\right), 4.04(1 \mathrm{H}, \mathrm{dd}, J=9.5,5.6 \mathrm{~Hz}$, methine), 4.47, $4.76\left(\overline{2} \mathrm{H}, \mathrm{d}, J_{\mathrm{gem}}=16.6 \mathrm{~Hz}, 2\right.$-furanylmethyl $), 6.35-6.40(2 \mathrm{H}, \mathrm{m}$, furan $), 7.13(1 \mathrm{H}, \mathrm{bs}$, imidazole), 7.47 (1H, bs, furan), 7.51 (1H, bs, imidazole), 8.16 $(1 \mathrm{H}, \mathrm{bs}$, imidazole).

\subsection{Methyl (S)-(-)-2-[(2-furanylmethyl) $(1 \mathrm{H}$-im-} idazol-1-ylcarbonyl)amino] butanoate (IIIb)

Starting from methyl $(S)-(+)$-2-aminobutanoate hydrochloride, compound IIIb was prepared by the same method as for compound IIIa.

Compound IIIb was confirmed by CI-MS and ${ }^{1} \mathrm{H}$ NMR spectra. mp $42-43^{\circ} \mathrm{C}$ (recrystallized from $n$ hexane). $\quad[\alpha]_{\mathrm{D}}^{20}-4.1^{\circ}(c=10.2$, methanol $)$.

\section{Determination of Chemical Purity}

The chemical purities of the racemates (II, III) and their optical isomers (IIa, IIb, IIIa, IIIb) were measured by high performance liquid chromatography (HPLC) analysis based on peak area percentage with a Shimadzu 
LC-6A instrument equipped with a SPD-6A absorbance detector under the following conditions: column, TSKgel ODS-80TM $(4.6 \mathrm{~mm}$ i.d. $\times 25 \mathrm{~cm})$; eluent, acetonitrile/ $1 / 15 \mathrm{M} \mathrm{KH}_{2} \mathrm{PO}_{4}$ aqueous solution $=1 / 1(\mathrm{v} / \mathrm{v})$; flow rate, $1.0 \mathrm{ml} / \mathrm{min}$; detection wavelength, $220 \mathrm{~nm}$; column temperature, $40^{\circ} \mathrm{C}$.

The chemical purities of the compounds newly synthesized in this study were as follows: II: $97.59 \%$ (racemate), IIa: $97.75 \%$, IIb: 95.53\%, III: $99.40 \%$ (racemate), IIIa: 97.90\%, IIIb: $97.54 \%$.

\section{Determination of Optical Purity}

The optical purities of the $N$-methyl isomers IIa and IIb were measured by HPLC in comparison with the separated peak area of each isomer using the same apparatus as for chemical purity analysis. The operating conditions were as follows: column, ULTRON ES-OVM $(4.6 \mathrm{~mm}$ i.d. $\times 15 \mathrm{~cm})$; eluent, acetonitrile/BritonRobinson buffer $(\mathrm{pH} 8.0)=1 / 19(\mathrm{v} / \mathrm{v})$; flow rate, $1.5 \mathrm{ml} /$ min; detection wavelength, $225 \mathrm{~nm}$; column temperature, room temperature.

The optical purities of the methyl ester isomers IIIa and IIIb were also measured under the following HPLC conditions: column, ULTRON ES-OVM $(4.6 \mathrm{~mm}$ i.d. $\times$

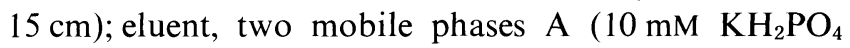
aqueous solution) and $\mathrm{B}$ (methanol/10 $\mathrm{mM} \mathrm{KH}_{2} \mathrm{PO}_{4}$ aqueous solution $=3 / 17, \mathrm{v} / \mathrm{v}$ ) were used; flow rate, 1.0 $\mathrm{ml} / \mathrm{min}$; detection wavelength, $220 \mathrm{~nm}$; column temperature, $35^{\circ} \mathrm{C}$. Elution was performed with $75 \%$ of mobile phase A and $25 \%$ of mobile phase B for the first $2 \mathrm{~min}$. A linear gradient of elution from $25 \%$ to $95 \%$ of mobile phase B was performed for the next $38 \mathrm{~min}$, and then $5 \%$ of mobile phase A and $95 \%$ of mobile phase B was used for the final $10 \mathrm{~min}$.

The optical purities of the compounds newly synthesized in this study were as follows: IIa: $97.6 \% e e, \mathbf{I I b}$ 81.7\% ee, IIIa :100\% ee, IIIb: $96.6 \% e e$.

\section{Test Organisms}

The fungi used in this study were Gibberella fujikuroi (benzimidazole-sensitive strain), Cochliobolus miyabeanus and Pyricularia oryzae.

\section{Antifungal Test by Agar Dilution Method ${ }^{5)}$}

Each racemate (I, II) and optical isomers (Ia, Ib, IIa, IIb) in acetone were added to a potato dextrose agar (PDA) medium $(50 \mathrm{ml})$. Acetone was evaporated to obtain the desired concentration. After $10 \mathrm{ml}$ of agar medium containing a test compound was poured into a petri dish (90 $\mathrm{mm}$ in diameter), a mycelial disc of fungus ( $3 \mathrm{~mm}$ in diameter) was placed on the center of the PDA medium. After incubation at $28^{\circ} \mathrm{C}$ for 3 or 4 days, the diameter of the mycelial colony was measured and mycelial growth inhibition was calculated percentagewise in comparison with the control. Dose-response curves and $\mathrm{EC}_{50}$ values (50\% effective concentration) were obtained from probit conversion of mycelial growth inhibition (\%) and the logarithm of the concentration (ppm) (Fig. 2).

\section{Inhibition of Ergosterol Biosynthesis in G. fujikuroi}

Effects on ergosterol biosynthesis of optical isomers (IIa, IIb) of pefurazoate $N$-methyl analogues were studied using a method previously reported ${ }^{3)}$ with ${ }^{14} \mathrm{C}$-acetate as a precursor for fungal lipids. Total lipids were extracted with chloroform and methanol (chloroform/ methanol $=1 / 2, \quad \mathrm{v} / \mathrm{v}){ }^{3,6)}$ Then the amounts of ${ }^{14} \mathrm{C}$ labeled lipid fractions separated by thin-layer chromatography (24-MDL, obtusifoliol, ergosterol and other lipids) were measured by autoradiography. ${ }^{3)}$

\section{X-Ray Analysis}

Pefurazoate racemate (I), its optical isomers $(\mathbf{I a}, \mathbf{I b})$ and pefurazoate $N$-methyl analogues (II, IIa, IIb) could not be examined by X-ray analysis because they were all oily substances, and therefore crystalline methyl ester racemate III, its $(R)-(+)$-isomer IIIa and allyl ester racemate IV were subjected to X-ray analysis in order to predict the conformations of optical isomers Ia, Ib, IIa and IIb.

Crystals of III, IIIa and IV for X-ray analysis were prepared by recrystallization from $n$-hexane.

\subsection{Racemate III}

A colorless crystal of racemate III $(0.35 \times 0.35 \times 0.30$ $\mathrm{mm}$, recrystallized from $n$-hexane) was mounted on a Rigaku AFC N2-R diffractometer. All measurements were performed with graphite mono-chromated $\mathrm{CuK} \alpha$ radiation.

Crystal data: $\mathrm{C}_{14} \mathrm{H}_{17} \mathrm{~N}_{3} \mathrm{O}_{4}$, formula weight 291.31, mp $75-77^{\circ} \mathrm{C}$, monoclinic, $\mathrm{a}=19.230$ (2) $\AA, \mathrm{b}=7.141$ (1) $\AA$, $\mathrm{c}=14.126$ (2) $\AA, \beta=130.84(1)^{\circ}, \mathrm{V}=1467.6(3) \AA^{3}$, space group Cc (\# 9), $\mathrm{D}_{\text {calc }}=1.318 \mathrm{~g} / \mathrm{cm}^{3}, \mathrm{Z}=4, \mu(\mathrm{CuK} \alpha)=$ $7.8 \mathrm{~cm}^{-1}$. Of the reflections collected up to a maximum $2 \theta$ value of $125^{\circ}, 1168$ reflections were measured over $3.00 \sigma(\mathrm{Fo})$ level and used for determination of structure. The structure was determined by direct methods and refined by the full-matrix least-squares method. The final $\mathrm{R}$ value was 0.040 .

\section{2 (R)-( + )-Isomer IIIa}

A colorless crystal of IIIa $(0.30 \times 0.40 \times 0.08 \mathrm{~mm}$, recrystallized from $n$-hexane) was mounted on a Rigaku AFC 7R diffractometer. All measurements were performed with graphite mono-chromated $\mathrm{CuK} \alpha$ radiation.

Crystal data: $\mathrm{C}_{14} \mathrm{H}_{17} \mathrm{~N}_{3} \mathrm{O}_{4}$, formula weight $291.31, \mathrm{mp}$ $42-43^{\circ} \mathrm{C}$, orthorhombic, $\mathrm{a}=11.272$ (1) $\AA, \mathrm{b}=17.776$ (2) $\AA, c=7.638$ (1) $\AA, V=1530.4(3) \AA^{3}$, space group $P 2{ }_{1} 2{ }_{1} 2$ (\# 18), $\mathrm{D}_{\text {calc }}=1.264 \mathrm{~g} / \mathrm{cm}^{3}, \mathrm{Z}=4, \mu(\mathrm{CuK} \alpha)=7.87 \mathrm{~cm}^{-1}$. Of the reflections collected up to a maximum $2 \theta$ value of $120.1^{\circ}, 1054$ reflections were measured over $3.00 \sigma(\mathrm{I})$ level 
and used for determination of structure. The structure was determined by direct methods and refined by the full-matrix least-squares method. The final $R$ value was 0.044 .

\subsection{Racemate IV}

A colorless crystal of racemate IV $(0.40 \times 0.30 \times 0.05$ $\mathrm{mm}$, recrystallized from $n$-hexane) was mounted on a Rigaku AFC $7 \mathrm{R}$ diffractometer. All measurements were performed with graphite mono-chromated $\mathrm{CuK} \alpha$ radiation.

Crystal data: $\mathrm{C}_{16} \mathrm{H}_{19} \mathrm{~N}_{3} \mathrm{O}_{4}$, formula weight 317.34 , mp 69-71 ${ }^{\circ} \mathrm{C}$, monoclinic, $a=7.550$ (1) $\AA, b=15.148$ (3) $\AA$, $\mathrm{c}=14.271$ (1) $\AA, \beta=93.77(1)^{\circ}, \mathrm{V}=1628.6(4) \AA^{3}$, space group $\mathrm{P} 2_{1 / \mathrm{n}}(\# 14), \mathrm{D}_{\text {calc }}=1.294 \mathrm{~g} / \mathrm{cm}^{3}, \mathrm{Z}=4, \mu(\mathrm{CuK}$ $\alpha)=7.84 \mathrm{~cm}^{-1}$. Of the reflections collected up to a maximum $2 \theta$ value of $120.1^{\circ}, 1701$ reflections were measured over $3.00 \sigma(\mathrm{I})$ level and used for determination of structure. The structure was determined by direct methods and refined by the full-matrix least-squares method. The final $R$ value was 0.041 .

\section{RESULTS AND DISCUSSION}

\section{Antifungal Activity}

The $\mathrm{EC}_{50}$ values and the dose-response curves for racemates and enantiomers are shown in Table 1 and Fig. 2, respectively. Pefurazoate optical isomers Ia and Ib exhibited highly enantioselective antifungal activity against all three species of fungi. As determined by $\mathrm{EC}_{50}$ values against $G$. fujikuroi (Table 1), the $(S)-(-)$-isomer Ib was approximately thirty times as active as $(R)-(+)-$ isomer Ia, and twice as active as racemate $\mathbf{I}$. Against $C$. miyabeanus and $P$. oryzae, the $(S)-(-)$-isomer $\mathbf{I b}$ was approximately five to ten times as active as $(R)-(+)-$ isomer Ia. The upper graphs in Fig. 2 show that the dose-response curves of racemate and enantiomers of pefurazoate do not overlie each other. In contrast with pefurazoate, the $\mathrm{EC}_{50}$ value ratios of $N$-methyl analogues based on that of racemate II (II/II, IIa/II, IIb/II) were
1.0, 0.65 and 0.74 for G. fujikuroi, 1.0, 1.0 and 0.98 for $C$. miyabeanus, and 1.0, 0.77 and 0.80 for $P$. oryzae (Table 1). In addition, the dose-response curves of $N$-methyl analogues (II, IIa, IIb) for these three fungi lay nearly one upon another (Fig. 2). These results suggest that optical isomers of pefurazoate exhibit highly enantioselective antifungal activity, while optical isomers of the $N$-methyl analogues do not differ in enantioselective activity. Interestingly, the antifungal activity of $N$-methyl analogues (II, IIa, IIb) against $P$. oryzae was much less than those against $G$. fujikuroi and C. miyabeanus, unlike pefurazoate (Table 1).

\section{Inhibition of Ergosterol Biosynthesis in G. fujikuroi}

The effects of $N$-methyl analogues (IIa,IIb) of pefurazoate on ergosterol biosynthesis are shown in Table 2 . In order to perform the inhibition test without significant effects of compounds on fungal growth, the test was conducted at $0.03 \mathrm{ppm}$ of isomers IIa and IIb. At this concentration, incorporation of ${ }^{14} \mathrm{C}$-acetate into the total lipids of G. fujikuroi was almost the same as untreated control (Table 2). When each $N$-methyl optical isomer of the pefurazoate analogues was added to the incubation mixture, 24-methylenedihydrolanosterol (24-MDL) and obtusifoliol (OF) accumulated, while ergosterol (ES) biosynthesis was suppressed by each $N$-methyl isomer to the same extent. In contrast, our previous study revealed highly enantioselective activity between pefurazoate $(R)-(+)$-isomer $\mathbf{I a}$ and $(S)-(-)$-isomer $\mathbf{I b}$ in the inhibition of ES biosynthesis in G. fujikuroi (Table 2). ${ }^{3)}$ These findings indicate that $N$-methyl optical isomers IIa and IIb also inhibited ES biosynthesis from 24-MDL, but that their potencies in inhibiting ES biosynthesis were similar.

\section{X-Ray Crystal Analysis and Molecular Shape}

Since the racemates and optical isomers of pefurazoate (I, Ia, Ib) and its $N$-methyl analogues (II, IIa, IIb) were

Table $1 \mathrm{EC}_{50}$ values of racemates and optical isomers of pefurazoate and its $N$-methyl analogues against G. fujikuroi, C. miyabeanus and P. oryzae.

\begin{tabular}{|c|c|c|c|c|c|c|}
\hline \multirow{2}{*}{ Fungus Compound } & \multicolumn{3}{|c|}{ Pefurazoate ${ }^{a)}$} & \multicolumn{3}{|c|}{$N$-Methyl analogue } \\
\hline & $\mathbf{I}^{\mathrm{b})}$ & $\mathbf{I a}^{\mathrm{c})}$ & $\mathbf{I}^{\mathrm{d})}$ & II $^{\mathrm{b})}$ & $\mathbf{I I}^{\mathrm{c})}$ & $\mathbf{I I}^{\mathrm{d})}$ \\
\hline \multirow[t]{2}{*}{ G. fujikuroi } & $0.49^{\mathrm{e})}$ & 7.35 & 0.24 & 0.34 & 0.22 & 0.25 \\
\hline & \multicolumn{3}{|c|}{$(1.0: 15: 0.49)^{\mathrm{f})}$} & \multicolumn{3}{|c|}{$(1.0: 0.65: 0.74)$} \\
\hline \multirow[t]{2}{*}{ C. miyabeanus } & 0.84 & 3.89 & 0.41 & 0.43 & 0.45 & 0.42 \\
\hline & \multicolumn{3}{|c|}{$(1.0: 4.6: 0.49)$} & \multicolumn{3}{|c|}{$(1.0: 1.0: 0.98)$} \\
\hline \multirow[t]{2}{*}{ P. oryzae } & 0.89 & 3.21 & 0.61 & 10.7 & 8.20 & 8.58 \\
\hline & \multicolumn{3}{|c|}{$(1.0: 3.6: 0.69)$} & \multicolumn{3}{|c|}{$(1.0: 0.77: 0.80)$} \\
\hline
\end{tabular}

a) $\mathrm{EC}_{50}$ values against $G$. fujikuroi of pefurazoate racemate $\mathbf{I}$ and its isomers $\mathbf{I}$ a and $\mathbf{I b}$ are taken from a previous report. ${ }^{3)}$ b) $\mathbf{I}$ and II are racemates. ${ }^{\text {c) }} \mathbf{I}$ a and IIa are $(R)$ isomers. d) Ib and IIb are $(S)$-isomers. e) $\mathrm{EC}_{50}(\mathrm{ppm})$. ${ }^{\text {f) }} \mathrm{EC}_{50}$ value ratio based on that of racemate $\mathbf{I}$ or II. 

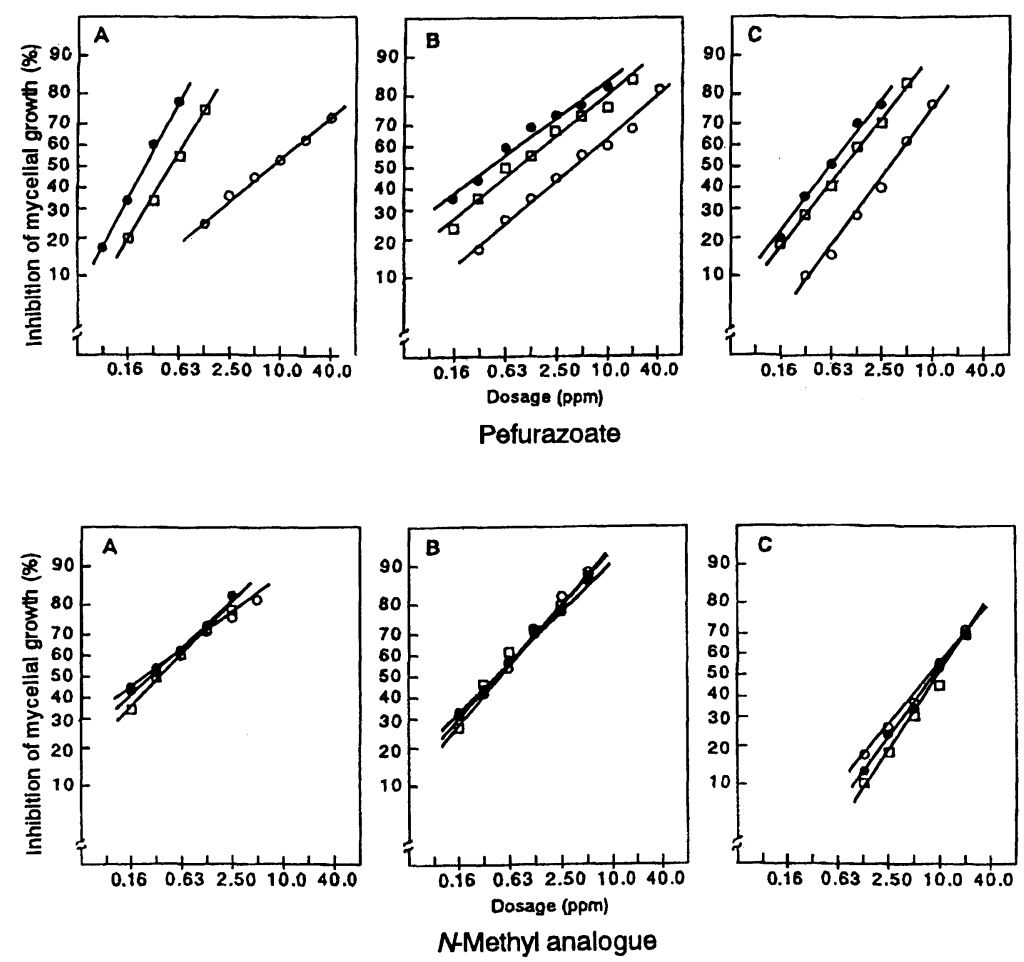

Fig. 2 Dose-response curves for racemates and optical isomers of pefurazoate (above) and its $N$-methyl analogues (below). A: G. fujikuroi, B: C. miyabeanus, C: P. oryzae.

Upper graphs; $\square:$ racemate I, $O:(R)-(+)$-isomer Ia, $\bullet:(S)-(-)$-isomer $\mathbf{I b}$.

Lower graphs ; $\square$ : racemate II, $\bigcirc:(R)-(+)$ - isomer IIa, $\bullet:(S)-(-)$-isomer IIb.

Table 2 Percentages of incorporation of $\left[2-{ }^{14} \mathrm{C}\right]$ acetate into lipid fractions of G. fujikuroi in the presence of optical isomers of pefrazoate and its $N$-methyl analogues.

\begin{tabular}{|c|c|c|c|c|c|}
\hline \multirow{2}{*}{$\begin{array}{l}\text { Compound } \\
\text { (Dosage) }\end{array}$} & \multicolumn{4}{|c|}{ Lipid fraction $(\%)^{a)}$} & \multirow{2}{*}{$\begin{array}{c}{ }^{14} \mathrm{C} \text {-acetate } \\
\text { incorporation into } \\
\text { total lipids (\%) }\end{array}$} \\
\hline & 24-MDL ${ }^{\mathrm{b})}$ & $\mathrm{OF}^{\mathrm{c})}$ & $\mathrm{ES}^{\mathrm{d})}$ & Others & \\
\hline $\begin{array}{l}\text { Untreated } \\
\text { control }\end{array}$ & 1.7 & trace & 10.3 & 88.0 & 4.5 \\
\hline $\begin{array}{c}(R)-(+) \text {-isomer IIa } \\
(0.03 \mathrm{ppm})\end{array}$ & 6.5 & 2.9 & 3.5 & 87.1 & 5.3 \\
\hline $\begin{array}{l}(S)-(-) \text {-isomer IIb } \\
(0.03 \mathrm{ppm})\end{array}$ & 6.6 & 3.1 & 2.6 & 87.7 & 5.6 \\
\hline $\begin{array}{l}\text { Untreated }^{\mathrm{e})} \\
\text { control }\end{array}$ & 4.8 & $-{ }^{\mathrm{f}}$ & 12.3 & 82.9 & 1.5 \\
\hline $\begin{array}{c}(R)-(+) \text {-isomer } \mathbf{I a}^{\mathrm{e})} \\
(7.35 \mathrm{ppm})\end{array}$ & 14.2 & - & 1.3 & 84.5 & 1.6 \\
\hline $\begin{array}{c}(S)-(-) \text {-isomer } \mathbf{I b}^{\mathrm{e})} \\
(0.24 \mathrm{ppm})\end{array}$ & 13.9 & - & 1.3 & 84.8 & 1.3 \\
\hline
\end{tabular}

all liquid substances, their X-ray crystal analysis was impossible. Instead of them therefore, crystalline methyl ester racemate III and allyl ester racemate IV of the pefurazoate analogues were subjected to X-ray analysis to predict the conformations of pefurazoate and its $N$-methyl analogues. X-Ray analysis of III and IV revealed that each racemate consisted of a pair of mirror symmetric $(R)$ - and $(S)$-confomers, and no other rotational confomers along the chiral carbon atom and its neighbouring nitrogen atom were observed (Fig. 3). The conformations of racemates III and IV were very similar except for the opposite orientation of their car- 

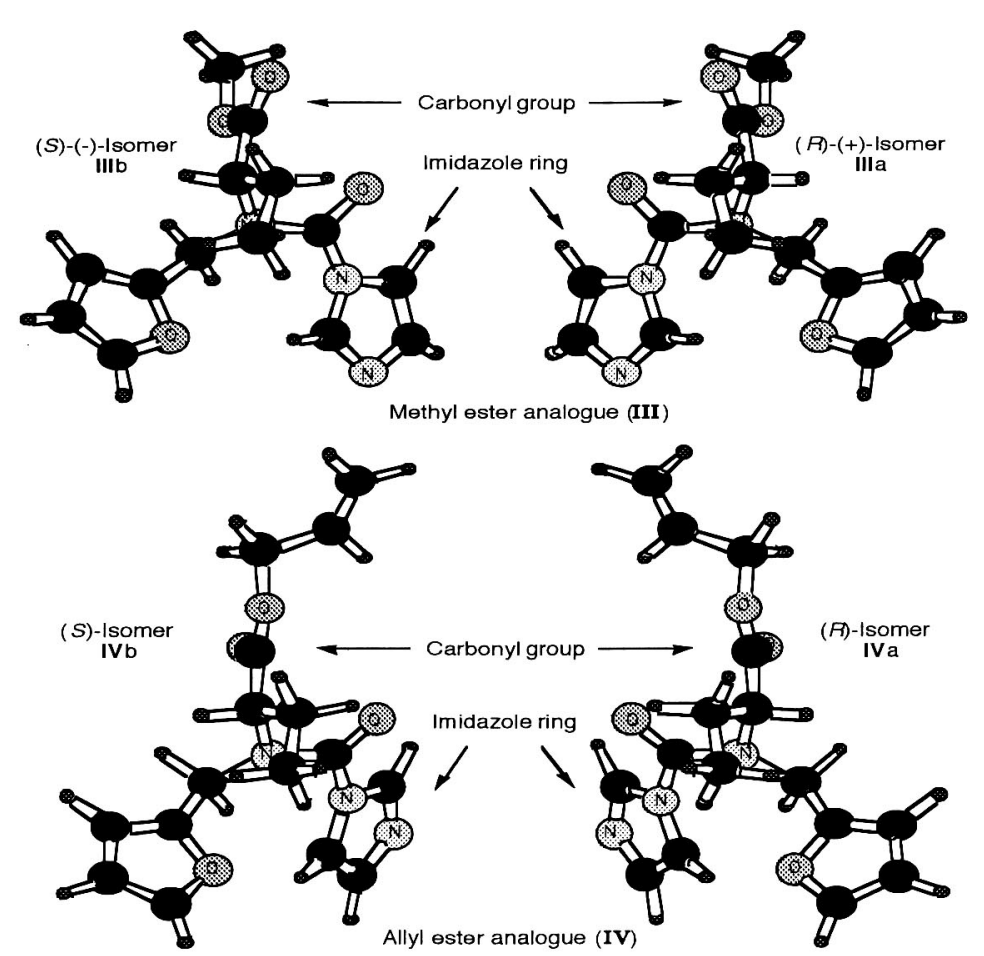

Fig. 3 X-Ray crystallographic structures of methyl ester racemate III and allyl ester racemate IV.

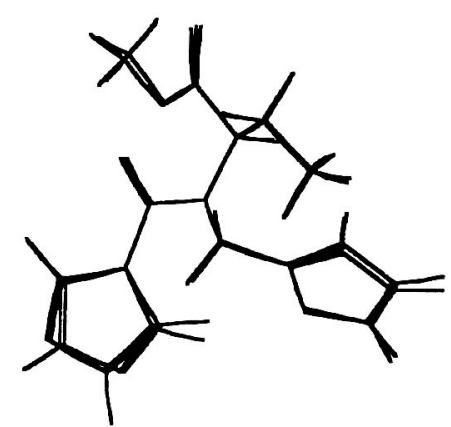

Fig. 4 Superimposition of X-ray crystal structure of the methyl ester of $(R)$-isomer IIIa observed in racemate III on that of $(R)-(+)$-isomer IIIa.

bonyl groups in the ester moiety and imidazole rings. Furthermore, as shown in Fig. 4, the X-ray crystal structure of the methyl ester of $(R)$ - $(+)$-isomer IIIa prepared separately was completely superimposed on that of $(R)$ isomer IIIa determined by X-ray analysis of racemate III. These results indicate that the conformations of these compounds are only slightly affected by molecular packing and the length of the ester moiety. Based on these findings, the molecular shapes of pefurazoate isomers $\mathbf{I} a$ and $\mathbf{I b}$ were constructed from the X-ray crystal structures of IIIa and IIIb, respectively, by extending the ester chain from the methyl group to a staggered 4-pentenyl group, and those of $N$-methyl optical isomers IIa and IIb were constructed from the molecular shapes of $\mathbf{I a}$ and $\mathbf{I} b$, respectively, by replacing
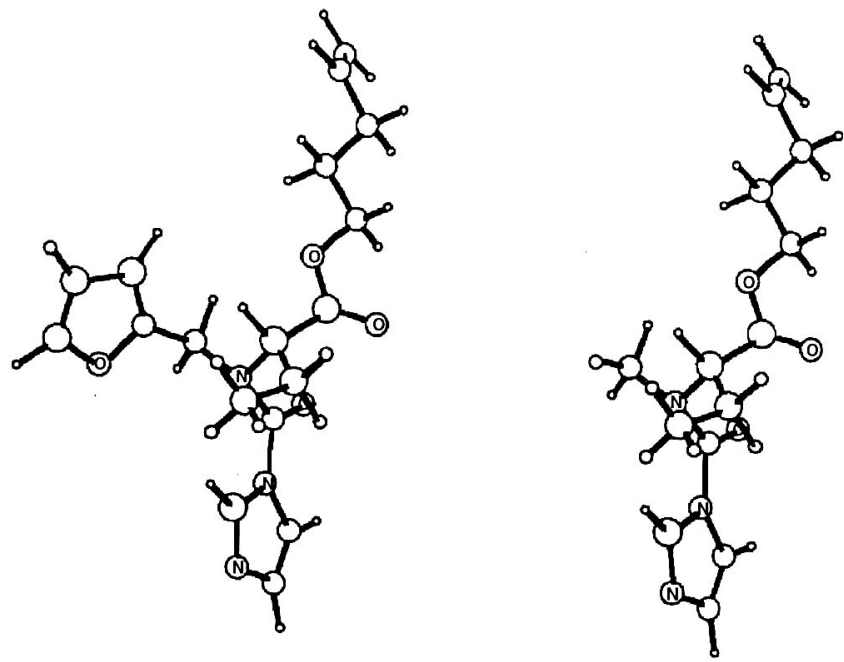

Fig. 5 Ball-and-stick models of pefurazoate $(S)$ - $(-)$-isomer Ib (left) and its $N$-methyl ( $S$ )-(-)-isomer IIb (right).

the 2-furanylmethyl group with a methyl group. The conformations thus obtained were optimized further by semi-empirical molecular orbital calculations using PM3 method $^{7,8)}$ in the MOPAC program (version 6.00). The molecular shapes of pefurazoate $(S)-(-)$-isomer $\mathbf{I b}$ and $N$-methyl $(S)$-(-)-isomer IIb are shown in Fig. 5.

\section{Enantioselective Antifungal Activity and Ergosterol Biosynthesis}

Pefurazoate has been reported to be an inhibitor of 
$14 \alpha$-demethylation of 24-MDL., ${ }^{3,9,10)}$ Demethylation, as in the case of other azole fungicides, might be inhibited by the interaction between the imidazole N-3 atom of pefurazoate and the $\mathrm{Fe}$ atom of cytochrome $\mathrm{P} 450$. A recent report indicated that stereoisomers of an imidazole fungicide exhibited highly enantioselective antifungal activity against $G$. fujikuroi. ${ }^{11)}$ We previously found that the $(S)$-(-)-isomer Ib was the active ingredient of pefurazoate, and that it was about thirty times as active as $(R)-(+)$-isomer Ia against $G$. fujikuroi both in mycelial growth inhibition and ergosterol biosynthesis inhibition. ${ }^{3)}$ In the present study, the optical isomers of pefurazoate also exhibited highly enantioselective antifungal activity against $C$. miyabeanus and $P$. oryzae (Table 1 , Fig. 2). The relative order of enantioselective activity against the fungi was as follows: G. fujikuroi $>C$. miyabeanus $>P$. oryzae. In contrast, the two optical isomers of the pefurazoate $N$-methyl analogues (IIa, $\mathbf{I I b}$ ) exhibited very little difference not only in mycelial growth inhibition for these three fungi (Fig. 2) but in inhibition of ergosterol biosynthesis in G. fujikuroi (Table 2). Based on these findings, we examined the difference in enantioselective activity between pefurazoate and its $N$-methyl analogues by comparing their molecular shapes. As shown in Fig. 5, the furan ring of $(S)$-isomer of pefurazoate protruded to an extreme extent in a direction different from that of the imidazole ring. The relative locations of the furan and imidazole rings of the $(S)$-isomer were exactly opposite those of its $(R)$ isomer. In contrast, the $N$-methyl analogues of pefurazoate have no substituents as bulky as furan rings to affect enantioselective activity. These results clearly suggest that the space occupied by the furan ring at the nitrogen atom and the relative orientation of the ring affect enantioselective activity, and that the conformation of the $(S)$-isomer of pefurazoate is more favorable than that of its $(R)$-isomer for interaction with the $14 \alpha$ demethylation enzyme, cytochrome P450.

\section{ACKNOWLEDGMENTS}

We wish to express our thanks to Mr. Toru Ogawa of the Ube Scientific Analysis Laboratory Inc., for his assistance in analyzing the compounds we prepared. We are also grateful to the members of our laboratory for their valuable support.

\section{REFERENCES}

1) I. Yamane \& M. Takenaka: Noyaku-Jiho No. 383, 6 (1990) (in Japanese)

2) M. Takenaka \& I. Yamane: Japan Pesticide Information No. 57, 33 (1990)

3) M. Takenaka, S. Kimura, T. Tanaka \& T. Wada: J. Pesticide Sci. 17, 205 (1992)

4) H. Takano, Y. Oguri \& T. Kato: J. Pesticide Sci. 11, 373 (1986)
5) M. Takenaka, Y. Hirota, T. Tanaka, H. Sugiura, N. Kuroda, T. Wada \& M. Hiramatsu: J. Pesticide Sci. 18, 15 (1993)

6) E. G. Bligh \& W. J. Dyer: Can. J. Biochem. Physiol. 37, 911 (1959)

7) J. J. P. Stewart: J. Comput. Chem. 10, 209 (1989)

8) J. J. P. Stewart: J. Comput. Chem. 10, 221 (1989)

9) M. Takenaka, K. Hayashi, T, Ogawa, S. Kimura \& T. Tanaka: J. Pesticide Sci. 17, 213 (1992)

10) T. Wada, S. Kuzuma, M. Takenaka \& Y. Hirota: Ann. Phytopathol. Soc. Japan 57, 153 (1991) (in Japanese)

11) T. Imai, T. Uchida, K. Yamaguchi, H. Takao \& T. Goto: $J$. Pesticide Sci. 18, 375 (1993)

\section{要 約 \\ イネ種子病原菌に対するペフラゾエートのエナンチ 才選択的抗菌活性}

竹中允章，西村 孝，林 敬介

ペフラゾエートは, エルゴステロールの前駆体である24-

メチレンジヒドロラノステロールの $14 \alpha$ 位脱メチル阻害 剂であり，その化学構造には不斉炭素原子 1 個を有する. ペフラゾエートの $(S)$ - $(-)$ - 異性体は, $(R)-(+)$-異性体 に比べ, イネばか苗病菌に約 30 倍の抗菌活性を示すことを 既に報告した。この抗菌活性におけるエナンチオ選択性の 要因は, 不斉炭素原子に隣接する窒素原子に立体的に嵩高 い2-フラニルメチル基が置換しているためであると考え られた。 そこで, このぺフラゾエートのエナンチオ選択的 抗菌活性の要因を立証するため, ペフラゾエートの $N$-メ チル類縁体の $(R)-(+)$-異性体と $(S)-(-)$-異性体を合成 し,それらの菌叢生育阻止試験による抗菌活性を検定した。 ペフラゾエートはイネばか苗病菌と同様，イネごま葉枯病 菌およびイネいもち病菌に対してもエナンチオ選択的抗菌 活性を示したが, ペフラゾエートの $N$-メチル類縁体では, これら 3 種の病原菌に対しエナンチオマー間の活性差はほ とんど認められず, また, ${ }^{14} \mathrm{C}-$ 酢酸を基質にしたイネばか苗 病菌のエルゴステロール生合成阻害程度においてもエナン チオマー間での選択活性を示さなかった。 そこで，その要 因を考察するため, ペフラゾエートとその $N$-メチル類縁 体の $(R)$-および $(S)$-異性体の安定分子形状を相互に比較 検討した。 ペフラゾエートとその $N$-メチル類縁体のエナ ンチオマーは，いずれも油状液体であり，X-線構造解析が 困難なため, 結晶で得られたぺフラゾエート誘導体の単結 晶 $\mathrm{X}$ 線構造解析を行いコンピューターによる構造の最適 化によりぺフラゾエートとその $N$-メチル類縁体の安定立 体構造を求め, それらの形状を比較した。その結果, フラ ン環部分以外のペフラゾエートの安定分子形状は, $N$-メチ 儿類縁体のそれと類似していた。フラン環を有しない $N-メ$ チル類縁体では， $(R)$-および $(S)$-異性体間で抗菌力と工 ルゴステロール生合成阻害力に差が認められないことよ ク，ペフラゾエートにおけるフラン環の占める空間とその 配向の違いが抗菌力とエルゴステロール生合成阻害におけ るエナンチオ選択活性の要因であると推察された. 